O. Yakimov, S. Uminsky, N. Klimenko, K. Kirkopulo, A. Pavlyshko, V. Vaysman, Odessa, Ukraine

\title{
IMPROVING GRINDING OF GEAR WHEELS APPLIED IN GEARBOXES OF POWER ENGINEERING
}

\begin{abstract}
Development of modem power engineering follows the line of continuous increase in speed, coefficient of corrosive action and capacity of units. Gears and reducers are responsible parts of modem machinery and occupy an important place in the domestic power engineering construction. Durability and wear resistance of gears, apart from the design factors, also depends on the technological methods of treatment. The final stage of production of such wheels is the operation of gear grinding. In the process of gear grinding in a thin surface ball there are complex thermomechanical processes. As a result of short-time heating to high temperatures, structural transformations, burns, and in some cases even micro- and macro-thicknesses occur in such a surface bail. In addition, there are cases of making tooth wheels with adjacent defects grinding (for example, the appearance of the surface of the ball teeth of large tensioning forces), which reduces the life of the work, and in some cases causes a breakdown of the teeth in operating conditions. Development of effective measures to ensure the quality of the surface of the ball on the operation of grinding baggage in part depends on the possibility of predicting (or calculation) of temperatures and residual loads on the depth of the cemented teeth ball. The method of calculation of internal surplus Toads occurring during grinding of wheels with cemented steels is suggested. On the basis of the performed calculations and experiments the ways to improve the quality of production of working surfaces of gears, which are used in the wits of thermal and nuclear power plants are suggested and grounded.
\end{abstract}

Keywords: cemented bal; surplus load; hard masti; overpowering circle.

Introduction. Development of modern power machine building follows the line of non- variable increase of speed, coefficient of corrosive action and capacity of units. In all cases where the optimal number of rotations of the unit motor differs significantly from the number of rotations of the operating mechanism, a gear reducer is used. Particular gears and reducers are crucial pats of modem mechanics and occupy an important place in ate of the-art power engineering. Durability and wear resistance of gears, in addition to design factors largely depends on the technological methods of processing.

Issue. Heavy-duty gear wheels are produced from cemented chromiummolybdenum and chromium-molybdenum-tungsten steels 12XH3A, 12X2H4A, $20 \mathrm{X} 2 \mathrm{H} 4 \mathrm{~A}$ and $18 \mathrm{X} 2 \mathrm{H} 4 \mathrm{MA}$. The final stage of production of such wheels is operation gear grinding. In the process of gear grinding in a thin surface ball there are complex and unique thermomechanical processes. As a result of short-term heating to high temperatures in the surface of the ball structural transformations occur, the so-called bums, and in some cases even micro and macro cracks.

(C) O. Yakimov, S. Uminsky, N. Klimenko, K. Kirkopulo, A. Pavlyshko, V. Vaysman, 2021 
Moreover, there are cases of toothed wheels produced with adjacent defects grinding (eg, the appearance of the surface ball teeth of large tensioning forces), which reduces the service life, and in some cases leads to a breakage of teeth in operating conditions. The development of effective measures to ensure the quality of the surface ball in the grinding operation depends in part on the possibility of predicting (or calculating) temperatures and residual loads on the depth of the cemented tooth ball.

Analysis of recent studies and publications. Mathematical modeling of thermal and strain-deformed state of the part material during grinding is the subject of the works [1-6]. Analytical determination of the values of deflecting residual stresses, taking into account the nonuniformity of carbon content in a grinded ball has not been given sufficient attention. The works [7,8] analyze the causes of surface bums and cracks during grinding of cemented gear wheels. In these works the adverse effects of grinding are proposed to reduce by optimizing the parameters of the cutting mode, and the formation of the stress-strain state of the surface ball during abrasive machining is considered mainly from the qualitative side or is, devoted to experimental study of the residual stresses.

Research Objective. To develop a method for calculating temperatures and residual stresses at different levels of the cemented ball, which occurs during grinding, and to suggest ways to improve the thermal and resilient-deformed state of the tooth surface ball in abrasive machining.

\section{Materials and methods of research.}

The general technique of researches was built on the basis of scientific bases of technology of mechanical engineering with attraction of the device of chemical thermodynamics, theory of vibration, and also on the basis of scientific representations on mechanics and thermal physics of processes of cutting. Experimental researches on comparative estimation of working ability of solid, discontinuous and discontinuous impregnated abrasive wheels were carried out on the surface grinding machine of 3G71M model. As investigated materials were used flat samples in the form of parallelepipeds with the sizes $150 * 20 * 10 \mathrm{~mm}$ from steel U10. During the experiments, wheels with dimensions of $200 * 20 * 76$ $\mathrm{mm}$ and characteristic 24A $40 \mathrm{CM} 27 \mathrm{~K} 6$ were used. Impregnating composition included oleic acid, acetamide and stearic acid.

Results of investigations. In the surface balls of cemented parts at grinding form stresses of different magnitude and sign. Residual stresses occur as a result of the interaction of plastic and plastic-deformed balls. If plastically deformed balls after cooling tend to increase their length in relation to their output length, then the plastically deformed balls tend to return to their output length. Thus, some of the balls will feel the tensile stress and others will feel the retracting stress. These loads remain in the part after grinding and therefore are called gaps. The main disadvantage of grinding is the occurrence of residual stresses of considerable 
magnitude, which can lead to cracking the surface of the cement bead. The reason for the occurrence of gapped stresses in the grinding process at an uneven phasestructural composition of the cemented ball is the grinding temperature, which leads to a nervous thermal expansion of its individual microspheres, which causes the occurrence of gapped stresses. When calculating the grinding temperatures two conditions must be taken into account: 1. Heat flux intensity is nervously distributed along the contact surface of the grinding wheel with the workpiece. At the beginning of the trajectory of passing the rust grain in the processed material the intensity of the heat flux is less, and at the end of the trajectory, where the overflow of chips is maximal, it is higher Thus, it is necessary to determine the temperature of the cutting surface taking into account the power of the heat fix, nervously dispersed on the contact surface of the grinding wheel with the metal. 2 . It is of practical interest to determine the temperatures that occur not only on the cutting surface (i.e. on the surface where the chip formations currently taking place) but also on the ground surface located below the cutting surface. In addition, for the calculation of the thermal surplus loads it is necessary to know how the temperatures of the globe of the cement ball are distributed. To solve the first problem, we select the coordinate system X,Y, Z on the surface of the bulked body. We assume that heats supplied to a certain region circumscribed by a rectangle, the sides of which are parallel to the axes $\mathrm{X}$ and $\mathrm{Y}$ :

$$
-a \leq x \leq a,-b \leq y \leq b, \text { де } a=\frac{\sqrt{D_{k p} \cdot t}}{2}, b=\frac{S}{2},
$$

$\mathrm{D}_{\mathrm{kp}}$ - diameter of the grinding wheel, $\mathrm{t}$ - depth of grinding, $\mathrm{S}$ - cross feed rate. Outside this area, there is no heat flow through the workpiece surface. Grinding depth, - transverse flow. Beyond this area, there is no heat flow through the workpiece surface. Heat source is considered non-perturbable, and the surface of the processed part is tom at a rate of speed $V_{\partial}$ in the direction of decreasing coordinate $x$. Let us consider a tired thermal regime when $\tau \rightarrow \infty$. For an elementary plane $D=d x \cdot d y$ with the center with coordinates $x, y$ the temperature distribution is described by dependence [9]:

$$
T_{1}(z)=\frac{q(x)}{2 \pi \lambda_{1}} \cdot \frac{1}{R} \exp \left(-\frac{V_{\partial} \cdot r+V_{\partial} \cdot\left(x_{0}-x\right)}{2 a_{1} \tau}\right),
$$

where $T_{1}$ - temperature on the cutting surface, ${ }^{\circ} \mathrm{C} ; x, y, z$ - current coordinates of the part position, $\mathrm{m} ; q(x)$ - thermal flux intensity in the given point at the contact point of the grinding wheel with the part, $\mathrm{Bm} / \mathrm{m}^{2} ; \lambda_{1}-$ coefficient of heat conductivity of the cutting surface, $\mathrm{W} / \mathrm{m} \cdot{ }^{\circ} \mathrm{C}$;

$$
R=\sqrt{\left(x_{0}-x\right)^{2}+\left(y_{0}-y\right)^{2}+z^{2}}
$$


Radius-vector of coordinates; $V_{\partial}$ - velocity of moving the part over the intact thermal source, $\mathrm{m} / \mathrm{min} ; \tau$ - moment of time, $\mathrm{s} ; x_{0}$-coordinate at the moment of $\tau_{0}, \mathrm{~m} ; \boldsymbol{r}$ - radius of rounding of cutting grain, $\mathrm{m} ; a_{1}$ - coefficient of thermal conductivity of cutting surface, $\mathrm{m}^{2} / \mathrm{s}$. By interpolating the expression (1) by area $\mathrm{D}$, we obtain:

$$
T_{1}(z)=\frac{1}{2 \pi \lambda_{1}} \int_{-a}^{+a} q(x) d x \int_{-b}^{+b} d y\left\{\frac{1}{R} \cdot \exp \left[-\frac{\mathbf{V}_{\text {म }} r+\mathrm{V}_{\text {म }}\left(x_{0}-x\right)}{2 a_{1} \tau}\right]\right\},
$$

where $a, b$ - half-width and full-width of the circle contact beaches with the piece, $\mathrm{m}$.

To solve the second problem, i.e. to bring the temperature at the top of the cutting to the temperature of the machined surface, it can be imagined that on this surface a body is driven, heated to temperature $T_{1}$ and composed of the material of the part, abrasive grit and the bonding of the stake. Each point of the ground surface is in contact with the body during the interval of time $\tau=\frac{\sqrt{D_{k p} \cdot t}}{V_{\partial}}$. In order to simplify the problem, we can assume that two interposed bodies with thermally insulated surfaces are brought into contact with each other at the initial moment of time. The temperature of the first body is equal to the temperature of the cutting surface $T_{1}$, and the temperature of the second body is equal to the temperature of the crushed surface $T_{2}$. It is necessary to find the temperature of the other body at the time from $\tau=0$ to $\tau=\frac{\sqrt{D_{k p} \cdot t}}{V_{\partial}}$.

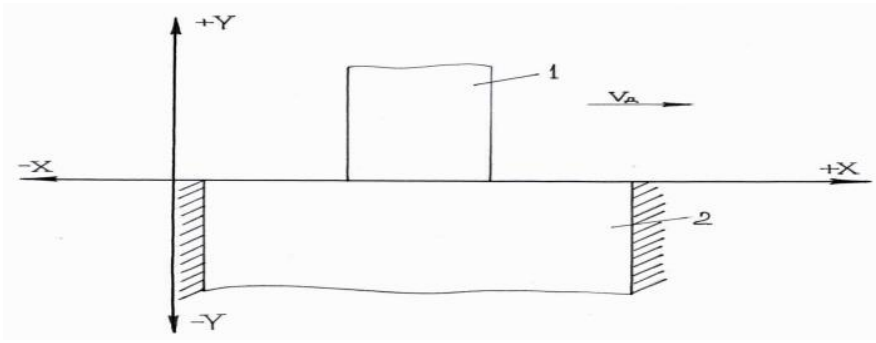

Figure 1 - Scheme for temperature calculation on the treated surface: 1 and 2 - bodies having at the initial moment of time the temperatures equal to the temperature of the cutting surface and the treated surface accordingly 
Thus, the problem is reduced to the solution of the heat transfer function at the boundary conditions of the 4th type, which corresponds to the contact of two solids with different temperatures. The difference heat transfer equation is written as follows:

$$
\begin{cases}\frac{\partial T_{1}(z, \tau)}{\partial \tau}=a_{1} \cdot \frac{\partial^{2} T_{1}(z, \tau)}{\partial z^{2}} & \text { at } \tau \geq 0 ; \mathrm{z} \geq 0 \\ \frac{\partial T_{2}(z, \tau)}{\partial \tau}=a_{2} \cdot \frac{\partial^{2} T_{2}(z, \tau)}{\partial z^{2}} & \text { at } \tau \geq 0 ; \mathrm{z} \leq 0\end{cases}
$$

Boundary conditions:

$$
\begin{aligned}
& T_{1}(z, 0)=f_{1}(z) ; T_{2}(z, 0)=f_{2}(z) \\
& \frac{\partial T_{1}(+\infty, \tau)}{\partial z}=\frac{\partial T_{2}(-\infty, \tau)}{\partial z}=0 \\
& T_{1}(+0, \tau)=T_{2}(-0, \tau) \\
& \frac{\partial T_{1}(0, \tau)}{\partial z}=-\frac{\lambda_{2}}{\lambda_{1}} \cdot \frac{\partial T_{2}(0, \tau)}{\partial x}
\end{aligned}
$$$$
\text { at, } 0 \leq \tau \leq \frac{\sqrt{D t}}{\mathrm{~V}_{\text {д }}}
$$

where $\lambda_{2}$ - is the coefficient of heat conductivity of the treated surface, $\mathrm{W} / \mathrm{m} \cdot{ }^{\circ} \mathrm{C}$. Using Laplace transformation, we reduce the system (4) of differential equations to a system of algebraic square equations. The solution for the representation looks like:

$$
\begin{aligned}
& T_{L 1}(z, s)-\frac{T_{01}}{s}=B_{1} \exp \left(-\sqrt{\frac{s}{a_{1}}} z\right), \mathrm{z} \geq 0 \\
& T_{L 2}(z, s)=B_{2} \exp \left(-\sqrt{\frac{s}{a_{2}}}|z|\right), \mathrm{z} \leq 0
\end{aligned}
$$

where $a_{2}$ - coefficient of temperature penetrability of the treated surface, $\mathrm{m}^{2} / \mathrm{s}$. The residual solution for the images will be:

$$
\begin{aligned}
& T_{L 1}(z, s)=\frac{T_{0}}{s}-\frac{T_{0}}{\left(1+K_{\varepsilon}\right) s} \exp \left(-\sqrt{\frac{s}{a_{1}}} z\right), \mathrm{z} \geq 0, \\
& T_{L 2}(z, s)=\frac{K_{\varepsilon} T_{0}}{\left(1+K_{\varepsilon}\right) s} \exp \left(-\sqrt{\frac{s}{a_{2}}}|z|\right), \mathrm{z} \leq 0
\end{aligned}
$$


where $K_{\varepsilon}=\frac{\varepsilon_{1}}{\varepsilon_{2}}=\frac{\sqrt{\lambda_{1} c_{1} \gamma_{1}}}{\sqrt{\lambda_{2} c_{2} \gamma_{2}}}-$ the ratio of coefficients of thermal activity of dosed bodies, the heat source and the crushed surface.

Going to the tables of images, we have:

$$
\frac{T_{2}(z, \tau)-T_{02}}{T_{01}-T_{02}}=\frac{K_{\varepsilon}}{1+K_{\varepsilon}} \operatorname{erfc} \frac{|z|}{2 \sqrt{a_{2} \tau}}
$$

${ }^{\text {Or }} T_{2}(z, \tau)=\left(T_{01}-T_{02}\right) \frac{\varepsilon_{1}}{\varepsilon_{2}+\varepsilon_{1}} \operatorname{erfc} \frac{|z|}{2 \sqrt{a_{2} \tau}}+T_{02}$ Considering, $T_{02}=0$ we'll get it: $T_{2}(z, \tau)=\frac{T_{01} \varepsilon_{1}}{\varepsilon_{2}+\varepsilon_{1}} \operatorname{erfc} \frac{|z|}{2 \sqrt{a_{2} \tau}}$. considering, that $\operatorname{erfc}=(1-$ erf $)$ we get: $T_{2}(z, \tau)=\frac{T_{01} \varepsilon_{1}}{\varepsilon_{2}+\varepsilon_{1}}\left(1-\operatorname{erf} \frac{|z|}{2 \sqrt{a_{2} \tau}}\right)$, where $T_{01}=T_{1}-$ is the temperature at the cutting surface, ${ }^{\circ} \mathrm{C}$.

Thus, in view of the temperature on the cutting surface (2), the grinding temperature $T_{2}(z, \tau)$, is reduced to the machined surface, which takes into account that the power of the thermal source is nervinetrically distributed along the contact, beach and the grinding wheel on the workpiece and the thermal power at this point of the contact beach depends on the specific coordinate $x$, and is equal to:

$$
T_{2}(z, \tau)=\frac{\varepsilon_{1} \cdot \int_{-a}^{+a} q(x) d x \int_{-b}^{+b} d y\left\{\frac{1}{R} \cdot \exp \left[-\frac{\mathrm{v}_{\text {д }} r+\mathrm{V}_{\text {д }}\left(x_{0}-x\right)}{2 a_{1} \tau}\right]\right\}}{2 \pi \lambda_{1}\left(\varepsilon_{2}+\varepsilon_{1}\right)}\left(1-e r f \frac{z}{2 \sqrt{a_{2} \tau}}\right),
$$

where $\varepsilon_{1}, \varepsilon_{2}$ - coefficients of thermal activity according to the thermal source and the treated surface, $\mathrm{W} / \mathrm{m}^{2} \cdot{ }^{\circ} \mathrm{C}$.

The magnitudes of the residual pressures that occur at different levels of the cement ball can be determined by correlating with the equation:

$$
G_{2}(z)=\frac{E_{2} \alpha_{2} \varepsilon_{1} \int_{-a}^{+a} q(x) d x\left\{\frac{1}{R} \cdot \exp \left[-\frac{V_{\partial}^{2} r+V_{\partial}^{2}\left(x_{0}-x\right)}{2 \cdot a_{1} \cdot \sqrt{D_{k p} \cdot t}}\right]\right\}\left(1-\text { erf } \frac{z \cdot \sqrt{V_{\partial}}}{2 \sqrt{a_{2} \sqrt{D_{k p} \cdot t}}}\right)}{\left(2-2 \cdot \mu_{2}\right) \cdot 2 \pi \lambda_{1}\left(\varepsilon_{2}+\varepsilon_{1}\right)}
$$

where $E_{2}$ - modulus of the cement ball, Mpa; $\alpha_{2}$ - linear coefficient of thermal expansion of the cement ball, $1 /{ }^{\circ} \mathrm{C} ; \mu_{2}-$ Poisson's coefficient of the cement ball. The figure 2 shows the calculated curves describing distribution of inner loading 
by the depth of the cemented ball after grinding of 18X2H4BA steel at the cutting thickness $t=0,1 \mathrm{~mm}$ (without cooling) and $\phi=0,015$ in $\mathrm{mm}_{t}=0,015 \mathrm{~mm}$ (with cooling). From the graphs it is seen that in the measure of distance from the surface the tensioning forces decrease and pass into constraining ones. When grinding in the most severe mode (curve 2), the tightening resistances have the lowest value. The appearance of tensioning forces during grinding of gear wheels leads to a reduction of their total strength.

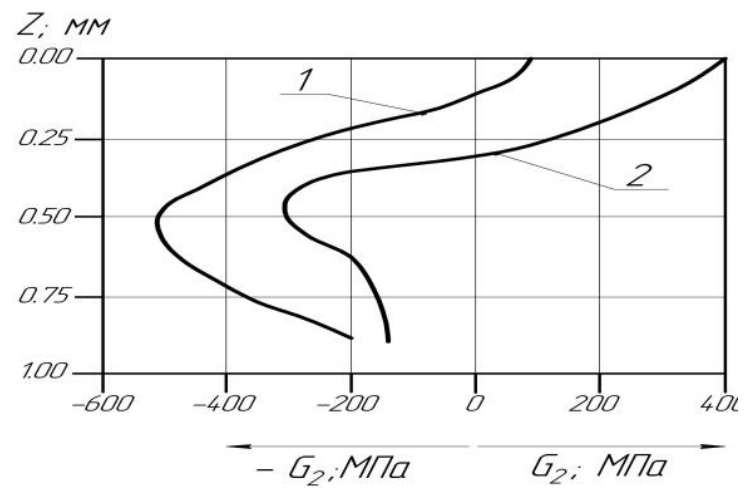

Figure 2 - Distribution of intrinsic surplus loads by the depth of the cement ball for two grinding modes: $t=0,015 \mathrm{~mm}$ and $t=0,1 \mathrm{~mm}$

Thermal and physical parameters of the treated material depend on the amount of carbon in the cement ball. Carbon in the cement ball is nervously distributed (Fig. 3). [8].

Figure 3 shows that increasing the concentration of carbon in the surface ball reduces the thermal conductivity $(a)$ and thermal conductivity $(\lambda)$ of the treated material. Calculation of internal residual stresses was carried out taking into account the graph s $a=f(c), \lambda=f(c)$. The appearance of grinding cracks is caused not only by filling and retention stresses, which occur during grinding and grinding when the temperature is cooled down to the martensitic transformation start point [11].

The reason for the formation of cracks are high contact temperatures and temperature gradient in the cutting zone, as well as high speeds of cooling the machined surface after the exit of its zone of contact with the abrasive wheel. In order to reduce the internal tensioning forces and the probability of fracture 
formation, it is necessary to reduce the temperature in the cutting zone and the speed of cooling by all available means [11].
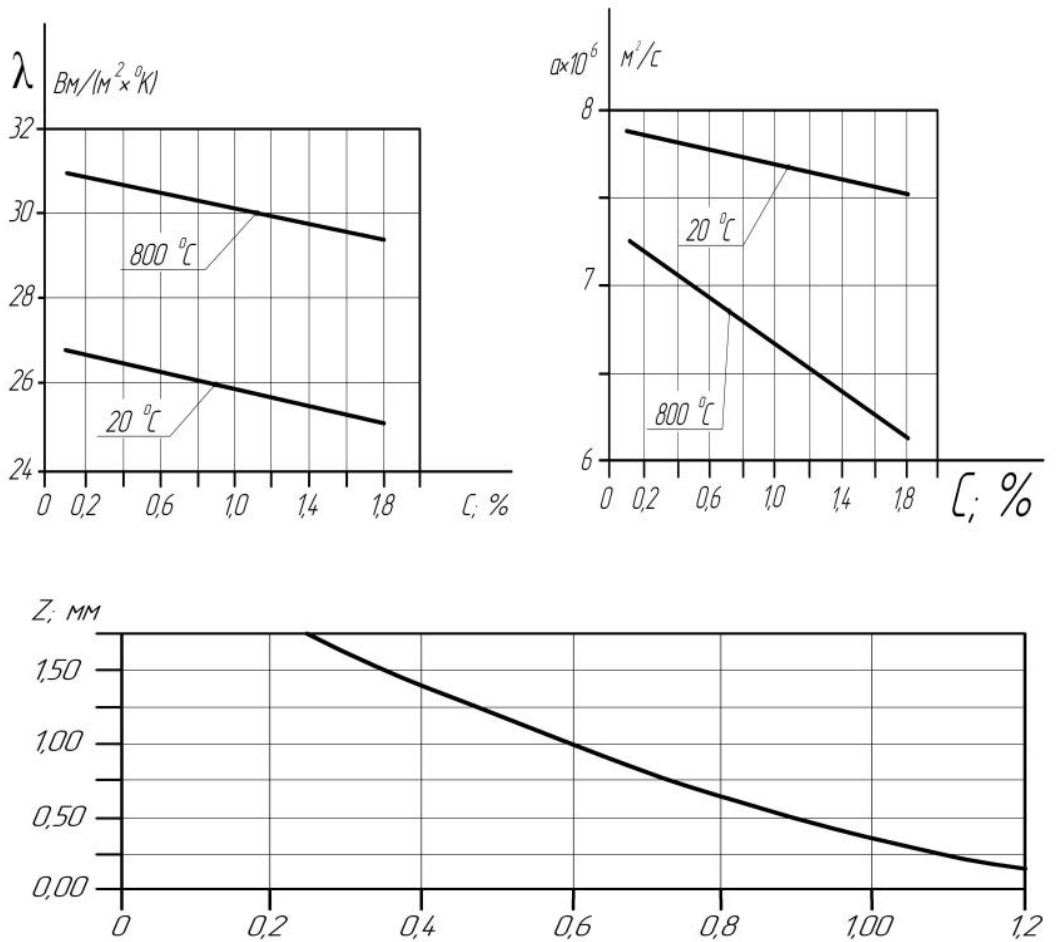

Figure 3 - Dependence of thermophysical parameters $(a, \lambda)$ of 18X2H4BA steel on the amount of carbon in the surface ball [10] at different temperatures and distribution of carbon over the depth of the cement ball [8]

This can be achieved by using as a coating and cooling agent a solid lubricant [12] whose components are taken in the following proportions: stearic acid (60 $65 \%)$, oleic acid (20 - 25\%), acetamide (others). The proposed lubricant, having a high sinking ability, significantly reduces the contact temperature of grinding at a very low speed of cooling of the surface balls of parts, which provides a reduction of internal tensioning forces occurring in the process of grinding [12]. Another effective way to reduce the contact temperature can be overflow grinding [13]. Under certain conditions, operation of a grinding wheel with an intermittent working surface can cause parametric resonance in the workbench rod system, 
which reduces the quality of the surface ball of the machined part. Parametric instability of the grinding machine rotary system is determined by the condition[14]

$$
|L|>\frac{M+1}{2}
$$

where $L$ and $M$ - parameters depending on the weight and rigidity of the rotary system of the workbench, the rheological capacity of the grinding wheel, number and sizes of pits and cutting protrusions on the working surface of the abrasive tool, the diameter and circumferential speed of the wheel, as well as the parameter characterizing the damped oscillations in time. Fig. 4 shows the areas of parametric stiffness of the workbench grinding system (flat colored plots) designed for intermittent grinding without using icing devices (two left space graphs) and with the use of solid lubricant (two right space graphs). Expansion of zones of stable work of the workbench's trunnion system at grinding with the use of solid abrasive is explained by the improvement of cutting ability of the abrasive tool in comparison with "dry" grinding. From the placement of two spatial graphs, rooted in the bottom of Fig. 4, it follows that the interval of change in the number of cutting interventions on the interval stake $5 \leq n \leq 20$ the size of areas stable work at grinding with a solid matrix at $35 \%$ more than for "dry" grinding. The area of these areas increased due to the reduced area of unstable work zones of the workbench system, i.e. due to the reduced area of the "hump" supports, which lie in the area described by the parameter $\frac{M+1}{2}$ (the right part of the nervousness (8)). Fig. 5 shows the experimental data on the measurement of loss of metal per hour unit $\mathrm{K}$. The experiments were carried out on the surface grinding machine of model ZG71M. Samples of the steel U10 were ground by dry, overfed $(\mathrm{n}=12, \mathrm{~N}=$ $0,6)$ and overfed by PP $250 \square 20 \square 76$ 24A 25CM2 $6 K 5$ wheels according to the parallel scheme (without the cross feed). The composition of the impregnator included stearic acid (60\%), oleic acid (20\%), acetamide (20\%).

Fig. 5 shows that during the initial period of time the metal atomic $(0 \leq \tau \leq 3)$ capacity was approximately the same for three investigated processes, and after the 18-minute grinding period the tensile strength of the grinding wheel became two times lower in comparison with the overexpanded and overprepared wheel.

Decrease in rust performance of the grinding wheel is accompanied by an increase in thermal stress of the grinding process and, as a result, formation of large internal residual stresses on the machined surface. 


\section{$\underline{\text { ISSN 2078-7405 Cutting \& Tools in Technological System, 2021, Edition } 95}$}
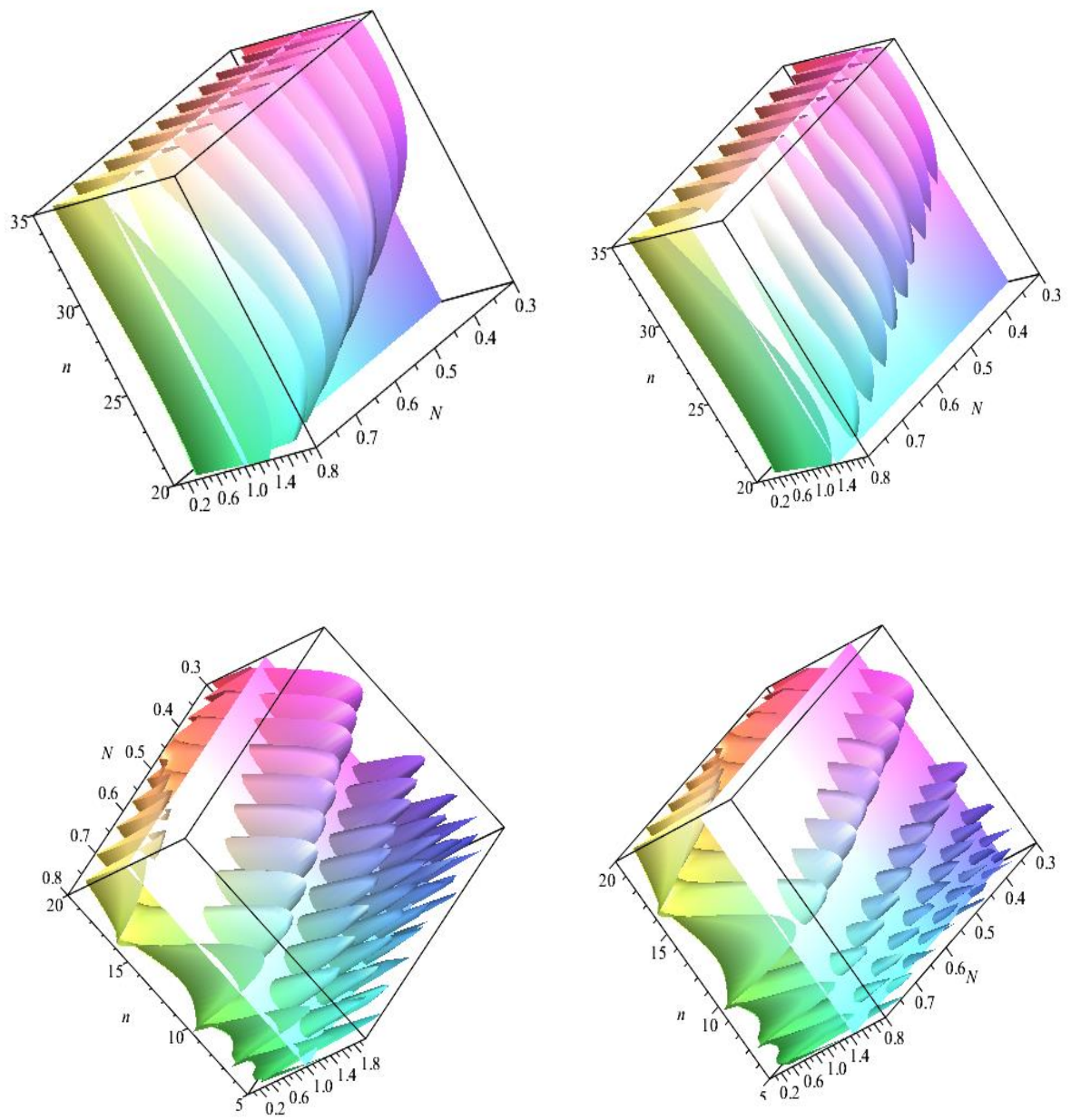

Figure 4 - Spatial graphs of dependence of parameters $L$ and $|L|>\frac{M+1}{2}$

on the number of cutting inserts on the abrasive stake and the value of the ratio of the stock width to the protrusion length: left- for "dry" grinding; right-hand - for grinding with the use of solid lubricant. 


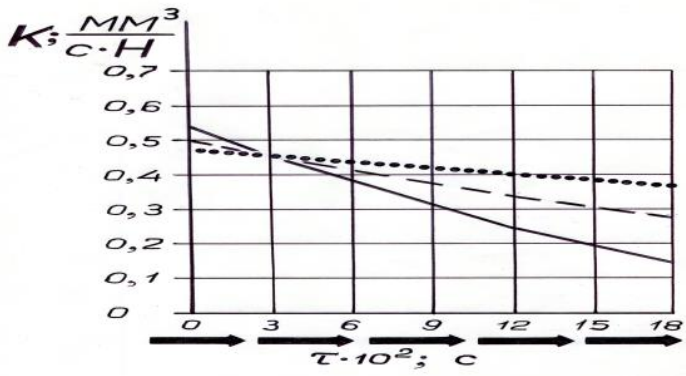

Figure 5 - Comparative estimation of the richer performance of the dry (non-interrupted line), over-interrupted (dashed line) and over-interrupted impregnated (dotted line) quill in time

Results. The method of calculation of internal residual loads occurring at grinding of wheels with cemented steels has been developed. On the basis of the performed calculations and experiments the ways to improve the quality of production of working surfaces of gears, which are used in the units of thermal and nuclear power plants are suggested and grounded.

References: 1. Korchak S.N. Theory of machinability of steels and alloys during abrasive machining / S.N. Korchak // Vestnik of South Ural State University: Collection of scientific works (Series "Mechanical Engineering"). - 2003. - №9. Vol.4 - pp. 82-90. 2. Viadimir Lebedev, Natalia Klimenko, Y. Uryadnikova, and other. Determination of the amount of heat released when cutting metal with an abrasive grain and the contact temperature of the ground surface. East European Journal of Advanced Technologies.-Ukrainian State University of Railway Transport, 2016. - N25(7). - pp. 43-50. 3. Lebedev Vladimir, Klimenko Natalia, Uryadnikova Inga, and other. Martensitic transformations in surface layer during grinding of hardened steel parts. East-European Journal of Advanced Technology, 2017 - Vol. 3, №12(87). 4. Melnikova, E.P. Influence of technological factors of finish abrasive machining on surface quality / E.P. Melnikova //Technology of Mechanical Enginee ing. - 2003. - №3. - pp. 13-16. 5. Usov A.V., Kunitsyn M.V. Possibilities of increasing the operational characteristics of the working surfaces of cylinders by technological methods. Bulletin of Kharkiv National Technical University. - Kherson National Technical University, 2018. - №2-3(66). 6. Usov A.V. Mathematical Modeling of Linear Non Homogeneous Systems by Methods of Singular Integral Equations. Journal of the Kherson National Technical University. - 2017. - №3(1), pp. 100-104. 7. Genkin M.D. Enhancement of reliability of heavy loaded gears / M.D. Genkin, M.A. Ryzhov, N.M. Ryzhov. Moscow: Mechanical engineering, 1981. - 232 p. 8. Sataradze V.S. Increasing the reliability of cemented parts / V.S. Sataradze. - Moscow: Mechanical engineering, 1975. - 216 p. 9. Redko S.G. Processes of heat formation when grinding metals / Saratov: Saratov University Press, 1986. - 231p. 10. Bakhvalov V.A. Research of influence of parameters of the process of gear grinding by cone wheel and input state of material on quality of surface layer: Ph. D. in Technical Sciences: 05.02.08 / - Odessa, 1977. - 350 p. 11. Oleksiy Yakimov, Liubov Bovnegra, Vladimir Tonkonogyi, Vladyslav Vaysman, 
Victor Strelbitskyi, Inna Sinko. Influence of the Geometric characteristics of the discontinuous profile working surfaces of abrasive wheels for precision and temperature during Grinding. Cutting and Tools in Technological Systems. - Khpi, 2021, №94. - pp. 115-125. https://doi.org/10.20998/20787405.2021.94.13. 12. Tonkonogyi Vladimir, Sidelnykova Tetiana, Dasic Predrag, Yakimov Alexey, Bovnegra Liubov. (2020). Improving the Performance Properties of Abrasive Tools at the Stage of Their Operation. |. Karabegovic (Ed.): NT 2019, LNNS 76, pp. 136-145, 2020. https://doi.org/10.1007/978-3-030-18072-0 15. 13. Vladimir Tonkonogyi, Alexey Yakimov, Liubov Bovnegra, Tetiana Sidelnykova, Predrag Dasic. The use of intermittent wheels, impregnated by the contact method to reduce the thermal stress of the grinding process/thansbud-2019. IOP Conf. Series: Materials Science and Engineering. pp. 1-11. 708(2019)012034, https://doi.org/10.1088/1757899X/708/1/012034. 14. F.V. Novikov, V.A. Zhovtobryukh, V.S. Gusarev, V.B. Naddachin, A.A. Yakimov, A.A. Andilakhai, A.S. Sergeev, D.F. Novikov Innovative development of modern technologies: monograph /. - Dnipro: Lira, 2021. - 480 p. ISBN 978-966- 981-519-4.

\author{
Олексій Якімов, Наталія Кліменко, Катерина Кіркопуло, \\ Андрій Павлишко, Сергій Уминський, Владислав Вайсман, Одеса, Україна
}

\title{
ЗАБЕЗПЕЧЕННЯ ЯКОСТІ ШЛІФУВАННЯ ЗУБЧАСТИХ КОЛІС, ЩО ВИКОРИСТОВУЮТЬСЯ В РЕДУКТОРАХ ЕНЕРГЕТИЧНОГО МАШИНОБУДУВАННЯ
}

\begin{abstract}
Анотація. Розвиток сучасного енергомашинобудування йде по лінії неперервного підвищення швидкостей, коефіиієнта корисної дії та потужностей агрегатів. І ие безумовно призводить до інтенсифікачії використання механізмів. Зубчасті передачі та редуктори є відповідальними частинами сучасних механізмів $i$ займають важливе місце $y$ вітчизняному енергомашинобудуванні. Міџність $і$ зносостійкість зубчастих передач, крім конструктивних факторів, залежить $i$ від технологічних прийомів обробки. Заключним етапом виготовлення таких коліс є операція зубошліфування. В процесі зубошліфовання в тонкому поверхневому шарі відбуваються складні термомеханічні процеси. В результаті короткочасного нагрівання до високих температур в такому поверхневому шарі виникають структурні перетворення, прижоги, а в деяких випадках навіть мікро і макротріщіни. Крім того, мають місце випадки виготовлення зубчастих коліс з прихованими дефектами шліфування (наприклад, появлення в поверхневому шарі зубів великих розтягуючих напруг). Це призводить до того, щцо знижується ресурс роботи механізмів, а в окремих випадках може викликати пошкодження зубів (в тому числі, призвести до поламки) в умовах експлуатації. Розробка ефективних заходів по забезпеченню якості поверхневого шару на операчії зубошліфування багато в чому залежить від можливості прогнозування (або розрахунку) температур і залишкових напружень по глибині цементованого шару зубів. Запропоновано методику розрахунку внутрішніх залишкових напружень виникаючих при зубошліфуванні коліс зі сталей, що цементуються. На основі виконаних розрахунків і експериментів було запропоновано, а також наведено обгрунтування щодо шляхів підвищення якості виготовлення робочих поверхонь зубчастих передач, щэо застосовуються в агрегатах теплових і атомних електростаниій.
\end{abstract}

Ключові слова: иементований шар; залишкові напруження; тверде мастило; переривчастий иліфувальний круг. 